\title{
ArcheoSciences
}

Revue d'archéométrie

\section{Pre-Columbian alloys from the royal tombs of Sipán and from the Museum of Sicán}

Non-destructive XRF analysis with a portable equipment

Alliages précolombiens des tombes royales de Sipán et du musée de Sicán:

analyse non-destructive avec un système FX portable

Roberto Cesareo, Angel Bustamante, Julio Fabian, Cristina Calza, Marcelino dos Anjos, Ricardo T. Lopes, Walter Alva, Luis Chero, Fidel Gutierrez, Maria del Carmen Espinoza, Rosendo Rodriguez, Marco Seclen, Victor Curay, Carlos Elera and Izumi Shimada

\section{OpenEdition}

\section{Journals}

Electronic version

URL: https://journals.openedition.org/archeosciences/2323

DOI: 10.4000/archeosciences. 2323

ISBN: 978-2-7535-1598-7

ISSN: 2104-3728

\section{Publisher}

Presses universitaires de Rennes

\section{Printed version}

Date of publication: 31 December 2009

Number of pages: $281-287$

ISBN: 978-2-7535-1181-1

ISSN: 1960-1360

Electronic reference

Roberto Cesareo, Angel Bustamante, Julio Fabian, Cristina Calza, Marcelino dos Anjos, Ricardo T. Lopes, Walter Alva, Luis Chero, Fidel Gutierrez, Maria del Carmen Espinoza, Rosendo Rodriguez, Marco Seclen, Victor Curay, Carlos Elera and Izumi Shimada, "Pre-Columbian alloys from the royal tombs of Sipán and from the Museum of Sicán", ArcheoSciences [Online], 33|2009, Online since 10 December 2012, connection on 28 January 2022. URL: http://journals.openedition.org/archeosciences/2323 ; DOI: https://doi.org/10.4000/archeosciences.2323 


\title{
Pre-Columbian alloys from the royal tombs of Sipán and from the Museum of Sicán: non-destructive XRF analysis with a portable equipment
}

\author{
Alliages précolombiens des tombes royales de Sipán et du musée de Sicán : \\ analyse non-destructive avec un système FX portable
}

\begin{abstract}
Roberto Cesareo*, Angel Bustamante**, Julio Fabian**, Cristina Calza ${ }^{* * *}$, Marcelino dos Anjos***, Ricardo T. Lopes ${ }^{* * *}$, Walter AlvA ${ }^{* * * *}$, Luis Chero****, Fidel Gutierrez ${ }^{* * * *}$, Maria del Carmen EspinozA ${ }^{* * *}$, Rosendo Rodriguez ${ }^{* * * *}$, Marco Seclen ${ }^{* * * *}$, Victor Curar*****, Carlos Elera ${ }^{* * * * *}$ and Izumi ShimadA ${ }^{* * * * *}$
\end{abstract}

\begin{abstract}
On the north coast of present-day Peru, approximately between 50 and 700 AD, flourished the Moche civilization. It was an advanced culture, and the Moche were sophisticated metalsmiths. The Moche metal working ability was impressively shown by the excavations of the “Tumbas Reales de Sipán”, discovered by W. Alva and co-workers in 1987.

The Sicán culture is a successive civilization (750-1375 AD) which extended as far as present day Piura in the north and Trujillo in the south. The Sicán culture was strongly influenced by the Moche culture, particularly in its metallurgical development (Shimada and Griffin, 1994).

The metal objects from the Museums of Sipán and Sicán were analyzed with a portable equipment which uses energy-dispersive X-ray fluorescence (XRF). This portable equipment is composed of a small size X-ray tube and a Si-PIN thermoelectrically cooled X-ray detector. It was determined that the analyzed artefacts are composed of gold, silver and copper alloys, of gilded copper, of silvered gold, and of tumbaga, the last being a poor gold alloy enriched at the surface by depletion gilding, i.e. removing copper from the surface.

In the case of gold, silver and copper alloys, their composition was determined by EDXRF analysis employing standard alloys. In the case of gilded copper, silvered copper and of tumbaga, the ratio $\mathrm{Cu}(\mathrm{K} \alpha / \mathrm{K} \beta)$ was accurately determined from the X-ray spectra, first in order to clearly distinguish them, and subsequently in order to determine the thickness of the gilding. Mean values of $0.4 \mu \mathrm{m}$ and $2.7 \mu m$ were determined for gilded copper and tumbaga, respectively. For gilded silver, the ratio $\mathrm{Ag}(\mathrm{K} \alpha / \mathrm{K} \beta)$ was measured. The ratios $\mathrm{Au}-\mathrm{K} \alpha / \mathrm{Cu}-\mathrm{K} \alpha, \mathrm{Ag}-\mathrm{K} \alpha / \mathrm{Cu}-\mathrm{K} \alpha$ and $\mathrm{Au}-\mathrm{K} \alpha / \mathrm{Ag}-\mathrm{K} \alpha$ (gilded copper, silvered copper, and gilded silver, respectively) also depend on the thickness of gilding or silvering, and were employed to this aim.
\end{abstract}

Résumé : Sur la côte nord de l'actuel Pérou, entre environ 50 et 700 AD, prospérait la civilisation Moche. Cette culture était très avancée et les Moches étaient des métallurgistes avertis. Leur talent pour travailler le métal est illustré par les fouilles du site des "Tumbas Reales de Sipán”, découvert par W. Alva et collaborateurs en 1987.

La culture Sicán est une civilisation qui se succède de 750 à 1375 AD et qui sétend au nord jusqu’à Piura et au sud jusqu’à Trujillo. La culture Sicán a été fortement influencée par la culture Moche, et tout particulièrement leur métallurgie (Shimada et Griffin, 1994).

Les objets métalliques des musées de Sipán et Sicán ont été analysés avec un spectromètre portable à fluorescence Xà dispersion d'énergie. Cet équipement est constitué d'un tube à rayons-X miniaturisé et d'un détecteur de rayons-X de type Si-PIN à refroidissement thermoélectrique. Nous avons pu montrer

* Dip. di Matematica e Fisica, Università di Sassari - Sassari, Italy. (cesareo@uniss.it)

** Universidad Nacional Mayor de San Marcos - Lima, Perù. (angelbd1@gmail.com)

*** COPPE, Universidade Federal do Rio de Janeiro - Rio de Janeiro, Brasil. (ricardo@lin.ufrj.br)

**** Museo "Tumbas Reales de Sipán”-Lambayequee, Perù. (museosipan@museosipan.com)

**** Museo de Sicán”-Ferrañafe, Perù. (museosican@speedy.com.pe) 
que les objets sont fabriqués avec des alliages d'or, argent et cuivre, avec du cuivre et de l'argent doré ainsi qu'avec du tumbaga, alliage d'or enrichi par mise en couleur, c'est-à-dire par appauvrissement en surface du cuivre.

Les compositions des alliages en or, argent et cuivre ont été déterminées par ED-FX au moyen de standards d'or. Pour différencier les cuivres et les argents dorés ainsi que les tumbaga et ensuite déterminer l'épaisseur de la dorure, le rapport $C u(K \alpha / K \beta)$ a été déterminé avec précision à partir des spectres à

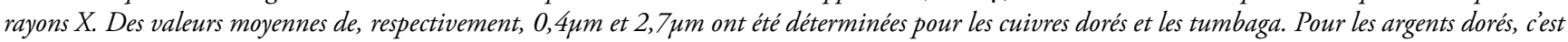
le rapport $A g(K \alpha / K \beta)$ qui a été mesuré. Les rapports $A u-K \alpha / C u-K \alpha, A g-K \alpha / C u-K \alpha$ et $A u-K \alpha / A g-K \alpha$ (cuivres dorés, cuivres argentés et argents dorés, respectivement) dépendent aussi de l'épaisseur de la dorure et de l'argenture.

Keywords: X-ray fluorescence, gold leaf thickness, Moche culture.

Mots-clés : Fluorescence à rayons X, épaisseur de feuille d'or, culture Moche.

\section{INTRODUCTION}

Objects belonging to the Moche civilization (Vetter Parodi, 2006; Alva, 2006) were analyzed in the past using various destructive techniques (Andrade et al., 2005; Burger, 1992; Lechtman, 1998; Ruvalcada Sil, 2005; Saettone et al., 2003; Scott, 2000); fragments of gold and silver artefacts (and also of silvered gold) from Loma Negra, Peru, were accurately studied and analyzed by Schorsch (1998) by employing EDXRF attached to a scanning electron microscope, and wave length dispersive X-ray Spectrometry. The gold objects showed the following composition: $\mathrm{Au}-80 \%$, $\mathrm{Ag}=10-20 \%, \mathrm{Cu}=5-15 \%$. The silver objects showed a high $\mathrm{Ag}$ content, of about $97-99 \%$. Copper represents the rest of the composition, to $100 \%$. An interesting and unusual feature is the case of silvered gold, with a silver sheet measured to have a thickness of about $5 \mu \mathrm{m}$.

Fragments from 17 Moche objects from the "Museo Tumbas Reales de Sipán" have been analyzed by Hörz and Kallfass (2000), using various techniques. These authors were able to identify: a) gilded copper objects: they are characterized by a thin gold film $(2-6 \mu \mathrm{m})$. The coatings consist of a gold-copper alloy containing some silver; b) coppersilver alloys: fragments from several human head shaped beads have been analyzed, showing a mean composition of $79 \% \mathrm{Cu}, 20 \% \mathrm{Ag}$, and $1 \% \mathrm{Au}$; c) copper-gold-silver alloys (tumbaga): fragments from a headdress, a chin ornament, an ornamental disc, and ornamental beads were analyzed; the average compositions were calculated to be varying between $20-60 \% \mathrm{Cu}, 35-65 \% \mathrm{Au}$ and $6-15 \% \mathrm{Ag}$. The alloy composition is strongly dependent on the distance from the surface.

For the systematic analysis of Sipán and Sicán metal objects, the use of non-destructive techniques may be proposed, and, among them, energy-dispersive X-ray fluorescence analysis (EDXRF) appears to be the most suited, because it is non-destructive, multi elemental, reliable, rapid, and may be carried out in situ (Cesareo et al., 2004). This method is able to quantify the composition of a gold or silver alloy when standard samples are used. EDXRF analysis provides reliable results regarding the concentration of high carat gold alloys with a reduced quantity of copper, and also in the case of high concentration copper or silver alloys. In the case of tumbaga, of copper-rich gold alloys, of gilded copper, and of copper-rich silver alloys, the results provided by EDXRF are incomplete or erroneous.

EDXRF is a surface analysis, and it is useful in this case because the respective thickness of the alloy is of the order of a few $\mu \mathrm{m}$ to a maximum of tens of $\mu \mathrm{m}$; because of this peculiarity, EDXRF is able to distinguish a gold alloy from gilded copper or tumbaga, and a silver alloy from gilded silver, by using the internal ratio of $\mathrm{Cu}$ and Ag-lines. The method is also able to determine the gold thickness value in the case of gilded copper or tumbaga gold.

\section{EXPERIMENTAL SET-UP}

The portable equipment employed for the analysis of Sipán and Sicán alloys is composed of an X-ray tube and a Si-PIN detector, both manufactured by AMPTEK. The X-ray tube has a weight of $300 \mathrm{~g}$, length of $17 \mathrm{~cm}$ - including the collimator - and diameter of $3.7 \mathrm{~cm}$. It has an $\mathrm{Ag}$-anode, and works at $30 \mathrm{kV}$ and $100 \mu \mathrm{A}$ maximum voltage and current. $\mathrm{X}$-rays from the tube irradiate areas of about $5 \mathrm{~mm}$ diameter, when the object is at a distance of $-2 \mathrm{~cm}$. The X-ray beam intensity is too high when alloys are analyzed, because the Si-PIN detector is able to process only a few thousands of photons/sec without losing energy resolution. The X-ray beam is therefore collimated with a brass cylinder $2 \mathrm{~cm}$ long and with an internal hole of $2 \mathrm{~mm}$ 


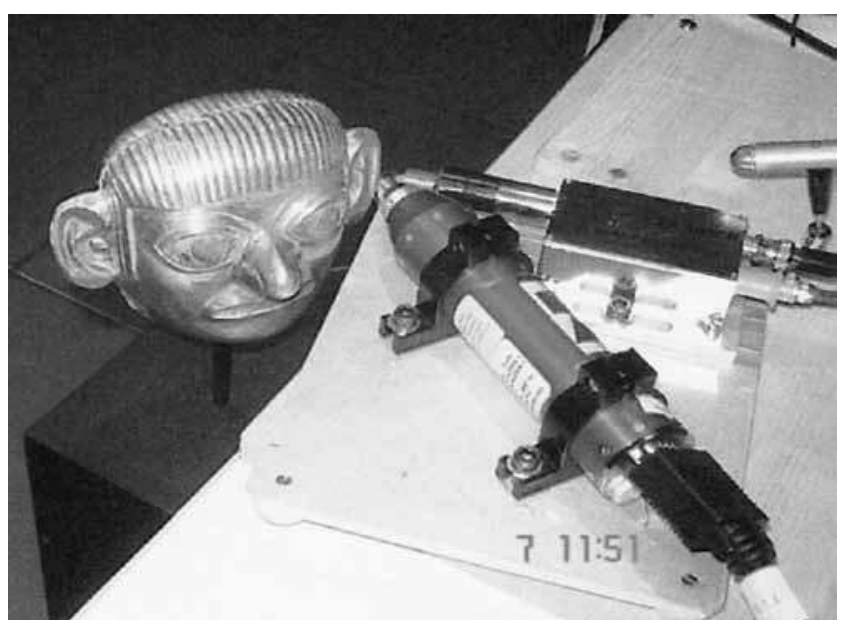

Figure 1: Experimental setup, showing, on the left, the Eclipse II X-ray tube and the Si-PIN detector (both collimated with a brass cylinder), measuring a Moche golden mask in the Museum “Tumbas Reales de Sipán”.

Figure 1 : Configuration expérimentale avec, sur la gauche, le tube à rayons-X Eclipse II et le détecteur Si-PIN (les deux collimatés avec un cylindre en laiton) pendant l'analyse du masque d'or Moche au musée "Tumbas Reales de Sipán".

in diameter. Furthermore, in order to excite silver in a more efficient manner, the X-ray tube output is also filtered with about $0.1 \mathrm{~mm}$ Ti.

The X-ray detector is a thermoelectrically cooled Si-PIN, with $300 \mu \mathrm{m}$ thickness, $7 \mathrm{~mm}^{2}$ area of the Si-crystal, and a thin Be-window. This detector has an energy resolution of about $180 \mathrm{eV}$ at $5.9 \mathrm{keV}$, and an efficiency of $90 \%, 25 \%$ and $8 \%$ at 10,20 , and $30 \mathrm{keV}$, respectively. It has a weight of $150 \mathrm{~g}$ and a length of $14 \mathrm{~cm}$. It is also collimated. The measuring time was of approximately $100 \mathrm{sec}$, according to sample composition and geometry.

Standard gold and silver alloys, with certified $\mathrm{Au}, \mathrm{Ag}$ and $\mathrm{Cu}$ concentrations, were employed for calibration and for the quantitative determination of the alloy composition.

In order to measure the gilding thickness of gilded gold or silver, the $\mathrm{Cu}(\mathrm{K} \alpha / \mathrm{K} \beta)$ or $\mathrm{Ag}(\mathrm{K} \alpha / \mathrm{K} \beta)$ ratios, and the $(\mathrm{Au}-\mathrm{L} \alpha / \mathrm{Cu}-\mathrm{K} \alpha)$ or $(\mathrm{Au}-\mathrm{L} \alpha / \mathrm{Ag}-\mathrm{K} \alpha)$-ratios were employed. $\mathrm{Au}$ leaves and $\mathrm{Ag}$ foils were employed for calibration (the foils were each $0.125 \mu \mathrm{m}$ and $0.28 \mu \mathrm{m}$ thick for Au and $\mathrm{Ag}$, respectively). Thick sheets of pure $\mathrm{Cu}$ and $\mathrm{Ag}$ were also employed. Thickness values were tested by transmission measurements with mono-energetic X-rays.

\section{THEORETICAL BACKGROUND}

\section{Quantitative analysis of gold, silver and copper alloys}

Artefacts of very different sizes, compositions and surfaces were analyzed. It is therefore very difficult to reproduce a fixed geometry. For this reason, determination of the alloy components on the basis of the fundamental parameters method is difficult, and an alternative approach was preferred, using the intensity ratio of two components (for example $\mathrm{Cu} / \mathrm{Au}$, assuming that $\mathrm{Au}(\%)+\mathrm{Cu}(\%)+\mathrm{Ag}(\%)=$ $100)$, which is not dependent on the geometry. Other elements present are determined by using fundamental parameters.

\section{Gilding thickness in gilded $\mathrm{Cu}$ (or $\mathrm{Ag}$ ) and in tumbaga through determination of $(\mathrm{K} \alpha / \mathrm{K} \beta)$, $(\mathrm{L} \alpha / \mathrm{L} \beta)$ - or $(\mathrm{Au}-\mathrm{L} \alpha / \mathrm{Cu}-\mathrm{K} \alpha)$-ratio, and $(\mathrm{Au}-\mathrm{L} \alpha /$ Ag-K $\alpha)$-ratios}

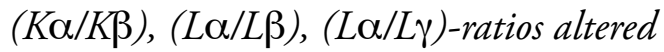 by self-attenuation}

The $\mathrm{K} \alpha / \mathrm{K} \beta, \mathrm{L} \alpha / \mathrm{L} \beta$ and $\mathrm{L} \alpha / \mathrm{L} \gamma$-ratios are tabulated (Cesareo, 2000; Markowicz, 1992). For example, for copper, $\mathrm{K} \alpha / \mathrm{K} \beta=7.4$, and for gold, $\mathrm{L} \alpha / \mathrm{L} \beta=1$. These values are valid for an infinitely thin sample, corresponding to a thickness $<1 \mu \mathrm{m},<0.5 \mu \mathrm{m}$ and $<0.2 \mu \mathrm{m}$ for $\mathrm{Cu}, \mathrm{Ag}$ and $\mathrm{Au}$, respectively. For larger thicknesses, self attenuation effects must be considered (Cesareo and Brunetti, 2008).

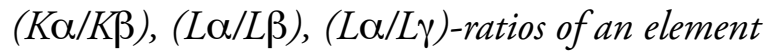
altered by attenuation by a second element

When a sheet of metal (a), for example copper, of infinite thickness, is covered by a sheet of another metal (b), for example gold, then the ratio $\left(\mathrm{K}_{\alpha} / \mathrm{K}_{\beta}\right)_{a}$ or $\left(\mathrm{L}_{\alpha} / \mathrm{L}_{\beta}\right)_{a}$ is altered because of the attenuation of the covering sheet:

$$
(K \alpha / K \beta)=(K \alpha / K \beta)_{\text {s.a. }} \exp -\left[\mu_{1}-\mu_{2}\right] d
$$

$(\mathrm{K} \alpha / \mathrm{K} \beta)_{\text {s.a. }}$ is the ratio of metal (a) according to possible self-attenuation; $\mu_{1}$ and $\mu_{2}\left(\mathrm{~cm}^{-1}\right)$ are the attenuation coefficients of element (b) at the energy of $K \alpha$ and $K \beta$ rays of element (a); $d$ is the thickness (in $\mathrm{cm}$ ) of the sheet of element (b) (Cesareo and Brunetti, 2008; Cesareo et al., 2009). Similar equations may be calculated for $L \alpha / L \beta$ and L $\alpha / \mathrm{L} \gamma$-ratios. 


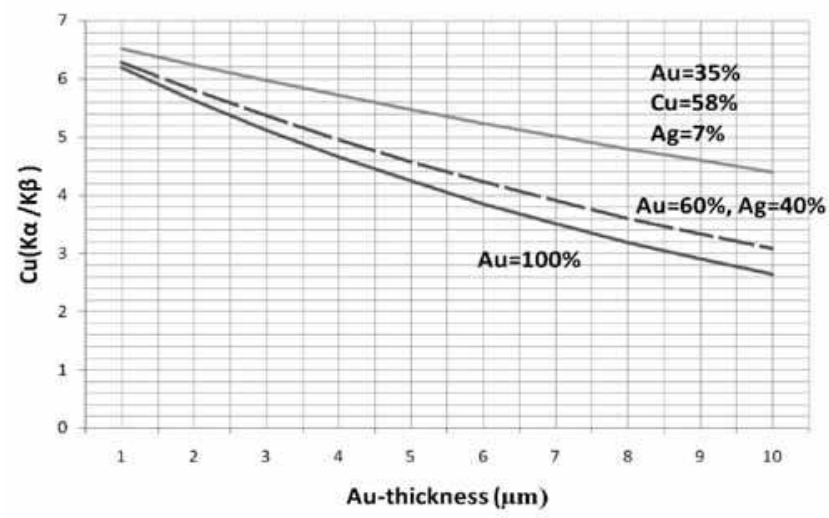

Figure 2: Gilded copper: attenuation of $\mathrm{Cu}(\mathrm{K} \alpha / \mathrm{K} \beta)$ ratio by $\mathrm{Au}$ (or Au alloys) vs Au thickness.

Figure 2 : Cuivre doré: atténuation du rapport $C u(K \alpha / K \beta)$ par l'Au (ou les alliages d'Au) versus l'épaisseur d'Au.

\section{$(A u-L \alpha / C u-K \alpha)$-ratio versus $A u$ thickness}

Another way to experimentally determine, from the X-ray spectrum, the thickness of the second element (b) assuming that the first element (a) has an infinite thickness is the use of the X-ray ratio of the two elements, for example, the ratio $(\mathrm{Au}-\mathrm{L} \alpha / \mathrm{Cu}-\mathrm{K} \alpha)$. This ratio, for two generic elements at fixed incident energy and geometrical arrangement, is provided by the following formula:

$$
\begin{aligned}
& \mathrm{N}_{\mathrm{b}} / \mathrm{N}_{\mathrm{a}} \propto \quad\left(\mu_{\mathrm{a} 0}+\mu_{\mathrm{aa}}\right) /\left(\mu_{\mathrm{b} 0}+\mu_{\mathrm{bb}}\right)\left[1-\exp -\left\{\mu_{0 \mathrm{~b}}+\mu_{\mathrm{bb}}\right\} \rho_{\mathrm{b}} \mathrm{d}_{\mathrm{b}}\right] \\
& \exp \left\{\mu_{0 \mathrm{~b}}+\mu_{\mathrm{ba}}\right\} \rho_{\mathrm{b}} \mathrm{d}_{\mathrm{b}}
\end{aligned}
$$

$-\mu_{\mathrm{a} 0}$ or $\mu_{\mathrm{b} 0}\left(\mathrm{in} \mathrm{cm}^{2} / \mathrm{g}\right)$ are the total mass attenuation coefficients of elements (a) and (b) at incident energy; $\mu_{\mathrm{ab}}$ (in $\mathrm{cm}^{2} / \mathrm{g}$ ) indicates the mass attenuation coefficient of element (a) at energy of the involved line of element (b); $\rho_{b}$ (in g/ $\mathrm{cm}^{3}$ ) is the density of element $b$.

In Equation (3), the proportionality should be quantitatively determined according to experimental data. Figure 3 represents theoretical values (from Eq. 3) and experimental measurements values for the $(\mathrm{Au}-\mathrm{L} \alpha / \mathrm{Cu}-\mathrm{K} \alpha)$-ratio versus $\mathrm{Au}$ thickness, assuming $\mathrm{Cu}$ with infinite thickness.

\section{Results}

\section{Alloys from “Tumbas Reales de Sipán”}

About 50 objects from the "Tumbas Reales de Sipán" were analyzed, made of gold, gilded copper, tumbaga, silver and

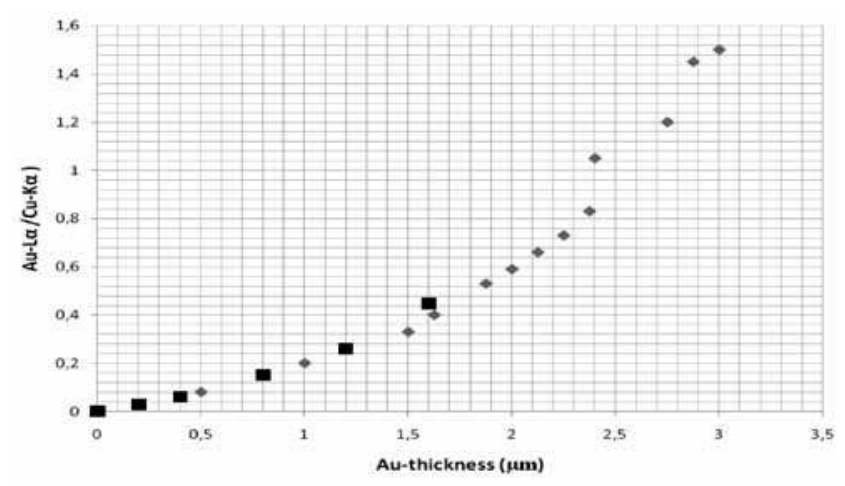

Figure 3: Theoretical (squares) and experimental values for (Au$\mathrm{L} \alpha / \mathrm{Cu}-\mathrm{K} \alpha$ ) ratio vs $\mathrm{Au}$ thickness, assuming $\mathrm{Cu}$ with infinite thickness.

Figure 3 : Valeurs théoriques (carrés) et valeurs expérimentales $d u$ rapport (Au-L $\alpha / C u-K \alpha)$ versus l'épaisseur d'Au, en assumant une épaisseur infinie pur le Cu.

copper alloys, the majority of them originating from the tomb "Señor de Sipán".

\section{Gold objects composition}

Several objects are made of gold (an example is shown in Fig. 4) and are characterized by $\mathrm{Au}, \mathrm{Cu}$ and $\mathrm{Ag}$ as main components. In some samples, traces of $\mathrm{Fe}, \mathrm{Zn}$ and $\mathrm{Br}$ are visible. The mean results of the EDXRF analysis carried out on gold objects are the following:

$$
\mathrm{Au}=69.5 \pm 7 \% ; \mathrm{Ag}=21 \pm 4 \% ; \mathrm{Cu}=9.5 \pm 5 \% .
$$

\section{Gilded copper: analysis and Au-thickness measurement}

Only a few objects are surely of gilded copper. They were identified by the exclusive presence of $\mathrm{Cu}$ in some analyzed areas, and by a deteriorated surface. In many cases, it was possible to clearly determine the Au leaf thickness from $\mathrm{Cu}$ $(\mathrm{K} \alpha / \mathrm{K} \beta)$ and $\left(\mathrm{N}_{\mathrm{Au}-\mathrm{L}} / \mathrm{N}_{\mathrm{Cu}-\mathrm{K}}\right)$ ratios.

Several sheets of gilded copper were analyzed. They are characterized by a $\mathrm{Cu}(\mathrm{K} \alpha / \mathrm{K} \beta)$ ratio of $6.1 \pm 0.1$, corresponding to a gilding thickness of $1.2 \pm 0.5 \mu \mathrm{m}$. From the $(\mathrm{Au}-\mathrm{L} \alpha / \mathrm{Cu}-\mathrm{K} \alpha)$ ratio of 0.1 results a value of $-0.5 \mu \mathrm{m}$, however. A beautiful mask of gilded copper was analyzed in detail, showing the following composition: $\mathrm{Au}-97.5 \%, \mathrm{Ag}$ $-2.5 \%$. The gilding thickness was measured to be $-0.5 \mu \mathrm{m}$. $\mathrm{Cu}$ could not be determined, because it was present below the gilding. 


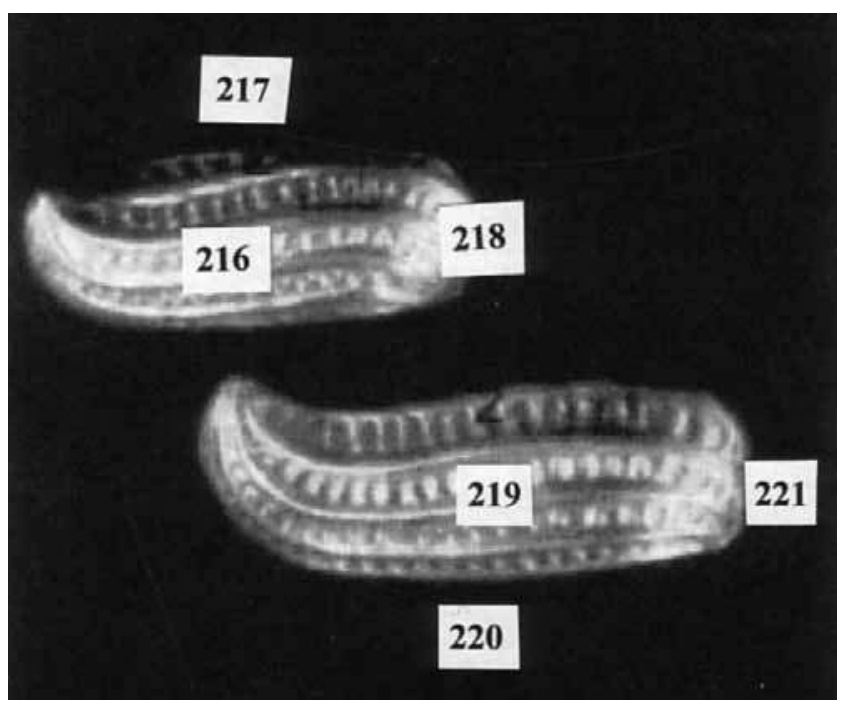

Figure 4: Peanut heads made of gold, belonging to a necklace. The average composition is: $\mathrm{Au}=58 \%, \mathrm{Ag}=26 \%, \mathrm{Cu}=16 \%$.

Figure 4 : Perles en forme de cacabuète exécutées en or et appartenant à un collier. D'après la Ref. (2). La composition moyenne est: $A u=$ $58 \%, A g=26 \%, C u=16 \%$.

\section{Tumbaga (or gilded copper) mean composition and gold thickness measurement}

The majority of the gold alloys were identified as tumbaga (an example is shown in Fig. 5), which behaves in a similar manner as gilded $\mathrm{Cu}$ for EDXRF analysis. The 'gold-equivalent' surface thickness can be determined from $\mathrm{Cu}-\mathrm{K \alpha} /$ $\mathrm{K} \beta$ and from $\left(\mathrm{N}_{\mathrm{Au}-\mathrm{L}} / \mathrm{N}_{\mathrm{Cu}-\mathrm{K}}\right)$ ratios (see Section 3). The mean $\mathrm{Au}-\mathrm{Cu}-\mathrm{Ag}$ concentration and $\mathrm{Au}$ thickness values are:

$\mathrm{Au}=60 \pm 10 \% ; \mathrm{Cu}=30 \pm 9 \% ; \mathrm{Ag}=10 \pm 4 \%$.

The $\left(\mathrm{N}_{\mathrm{Au}-\mathrm{L}} / \mathrm{N}_{\mathrm{Cu}-\mathrm{K}}\right)$ ratio $=1.44 \pm 0.7$, corresponding to an Au thickness of $3.10 \pm 0.7 \mu \mathrm{m}$;

The $(\mathrm{Cu}-\mathrm{K} \alpha / \mathrm{K} \beta)$ ratio $=5.35 \pm 0.5$, corresponding to an Au thickness of $2.5 \pm 1.4$.

\section{Silver objects}

The EDXRF analysis of silver objects shows that the silver content is relatively high, and that it systematically contains gold. The following mean concentration values were determined:

$$
\mathrm{Ag}=92 \pm 4 \% ; \mathrm{Cu}=5 \pm 2.5 \% ; \mathrm{Au}=3 \pm 1.5 \%
$$

\section{Copper objects}

Parts of a few objects are made of copper, composed of about $99 \% \mathrm{Cu}$, and traces of $\mathrm{Fe}$ and $\mathrm{Ni}$.

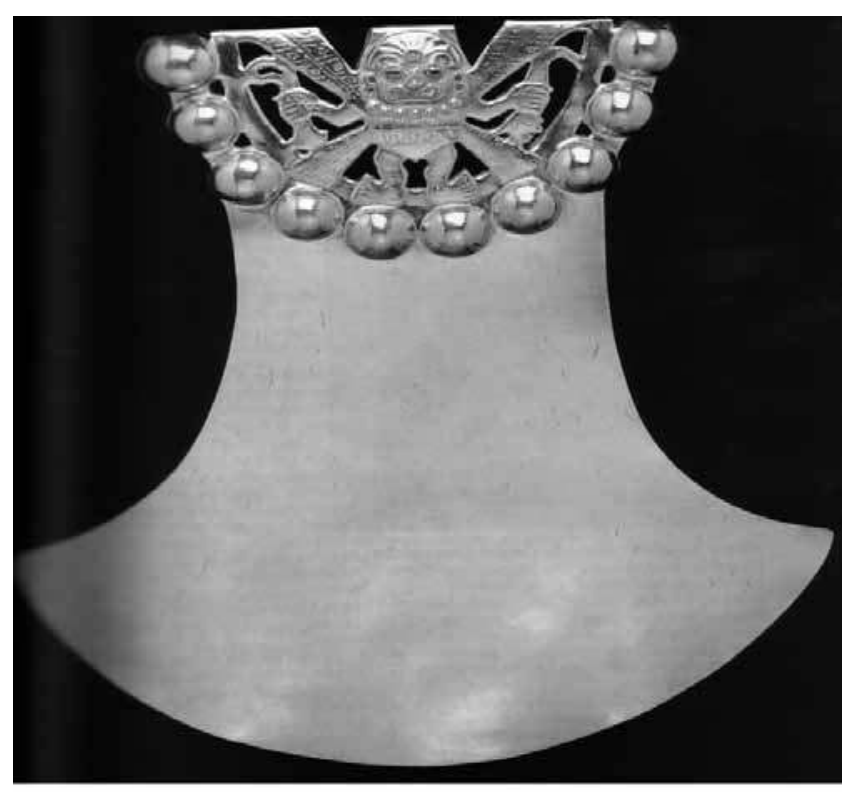

Figure 5: Leg protector made of tumbaga. The ratio $\mathrm{Cu}(\mathrm{K} \alpha / \mathrm{K} \beta)$ is 4.8 , corresponding to an Au thickness of $3.1 \mu \mathrm{m}$

Figure 5 : Protecteur de jambe en tumbaga. Le rapport $C u(K \alpha / K \beta)$ est 4,8, correspondant à une épaisseur d'Au de 3,1 $\mathrm{\mu m}$

\section{Turquoises}

Many of the gold objects include turquoise, which is a hydrated phosphate of aluminium and copper. The turquoise shows an occasional presence of $\mathrm{Zn}, \mathrm{Fe}$ and $\mathrm{Cr}$ as impurities, resulting in deviations from the blue colour. Results pertaining to Sipán turquoise show a systematic presence of $\mathrm{Fe}$ and $\mathrm{Zn}$, at an average concentration of $10 \%$ and $8.5 \%$, respectively.

\section{Alloys from the museum of Sicán}

About 20 objects from the Museum of Sicán (Shimada and Griffin, 1994) were analyzed, the majority of which were of gilded copper; others were made of gold, tumbaga, silver and copper alloys.

\section{Objects made of gold}

The following mean values could be determined:

$$
\mathrm{Au}=62 \pm 4 \% ; \mathrm{Ag}=32 \pm 3 \% ; \mathrm{Cu}=6 \pm 2 \% .
$$

\section{Objects made of gilded copper}

The following mean values could be determined for the gilding: $\mathrm{Au}=67 \% ; \mathrm{Ag}=33 \%$. 


\section{Objects made of tumbaga}

A few objects are of uncertain composition; they could either be made of gilded copper or of tumbaga. In fact, the gilded copper objects are identified because of the altered $\mathrm{Cu}(\mathrm{K} \alpha / \mathrm{K} \beta)$ ratio, and because of the presence of highly corroded areas on almost pure copper. In other cases, the ratio $\mathrm{Cu}(\mathrm{K} \alpha / \mathrm{K} \beta)$ is altered, but no corroded areas were detected.

One artefact, a beautiful mask, is certainly made of tumbaga, whose concentration and characteristic thickness parameters are the following:

$$
\mathrm{Au}=34 \pm 6 \% ; \mathrm{Cu}=57 \pm 5 \% ; \mathrm{Ag}=7 \pm 1.5 \% \text {. }
$$

The $\mathrm{Cu}(\mathrm{K} \alpha / \mathrm{K} \beta)$ ratio $=4.9 \pm 0.3$, corresponding to an $\mathrm{Au}$ thickness of $3.8 \pm 0.9 \mu \mathrm{m}$.

The $(\mathrm{Au}-\mathrm{L} / \mathrm{Cu}-\mathrm{K})$ ratio $=1.05 \pm 0.02$, corresponding to an Au thickness of $4.5 \pm 0.8 \mu \mathrm{m}$.

\section{Objects made of silver}

Only one object is made of silver, i.e. a brooch in the form of a monkey, with the following composition: $\mathrm{Ag}=94 \%$, $\mathrm{Cu}=3.7 \%, \mathrm{Au}=0.5 \%, \mathrm{~Pb}=0.8 \%, \mathrm{Br}=1 \%$.

\section{Objects made of copper}

The following mean values could be determined:

$\mathrm{Cu}=98 \pm 1 \% ; \mathrm{Fe}=1.2 \pm 0.5 \% ;$ As $=0.8 \pm 0.5 \%$.

\section{Conclusions}

EDXRF analyses of precious objects from Sipán and Sicán demonstrate their complexity and variety; they are made of the following alloys: gold, gilded copper, tumbaga, silver, silvered copper, silvered gold, copper, and so on, and their nature is not always easy to identify.

From the metallurgical point of view, a comparison between the Moche (50-700 AD) and Sicán (750-1375) civilizations shows that:

- Moche precious objects seem to be more sophisticated in terms of beauty and technology;

- The average compositions of gold and silver are similar;

- The Moche civilization largely used tumbaga-gold (representing more than $50 \%$ of the 'gold' artefacts), while Sicán used more gilded copper;

- The Moche employed almost pure copper; the Sicán civilization had a knowledge of arsenical copper.

\section{Acknowledgements}

This work was partially carried out within the framework of the project IAEA-CRP (G4.20.02/1371) "Unification of nuclear spectrometry: integrated techniques as a new tool for material research". J. Fabian expresses his gratitude to the International Centre for Theoretical Physics Abdus Salam for a 5 months grant at the University of Sassari.

\section{References}

Alva,W., 2006. SIPAN : descrubrimiento e investigation. Lima: Quebecor World Perù S.A.

Andrade, E., Murillo, G., Policroniades, R., Acosta, L., Zavala, E.P., Rocha, M.F. and Centeno, S.A., 2005. IBA analysis of some precolumbian gilded copper samples. Nuclear Instruments and Methods in Physics Research B 240: 570-575.

BURGER, R.L., 1992. Chavin and the origin of Andean civilization. London, Thames and Hudson Ltd.

Cesareo, R., 2000. X-Ray Physics, La Rivista del Nuovo Cimento. Bologna, Ed. Compositori.

Cesareo, R., Brunetti, A., Castellano, A. and Rosales, M.A., 2004. Portable equipment for X-ray fluorescence analysis, in K. Tsuji, J. Injuk, R.E. van Grieken (eds.), X-Ray Spectrometry: Recent Technological Advances. Chichester J. Wiley \& Sons, 307-341.

Cesareo, R. and Brunetti, A., 2008. Metal sheets thickness determined by energy-dispersive X-ray fluorescence analysis. Journal of X-Ray Science and Technology 16(2): 119-130.

Cesareo, R., Rizzutto, M.A., Brunetti, A. and Rao, D.V. Metallocation and thickness in a multilayered sheet by measuring $\mathrm{K} \alpha / \mathrm{K} \beta, \mathrm{L} \alpha / \mathrm{L} \beta$ and $\mathrm{L} \alpha / \mathrm{L} \gamma$ X-ray ratios. Nuclear Instruments and Methods in Physics Research B 267: 2890-2896.

Hörz, G. and Kallfass, M., 2000. The treasure of Au and Ag artefacts from the Royal Tombs of Sipán, Peru. Materials Characterization 45: 391-420.

Lechtman, H., 1998. New perspectives on Moche Metallurgy: techniques of gilding copper at Loma Negra, Northern Peru. American Antiquity 47(1): 3-30.

Markowicz, A.A., 1992. X-ray Physics, in R.E. van Grieken, A.A. Markowicz (eds.), Handbook of X-ray Spectrometry. New York: M. Dekker Inc., 1-92

Ruvalcada Sil, J.L., 2005. PIXE analysis of pre-Hispanic items from ancient America, in M. Uda, G. Demortier, I. Nakai (eds.), X-rays for archaeology, Dordrecht, Springer, 123-149.

Saettone, E.A.O., Matta, J.A.S., Alva, W., Chubaci, J.F.O., Fantini, M.C.A., Galvão, R.M.O., KiYohara, P. and TaвaCniKs, M.H., 2003. Plasma cleaning and analysis of archaeological artefacts from Sipán. Journal of Physics D: Applied Physics 36: 842-848. 
Schorsch, D., 1998. Silver and gold Moche artefacts from Loma Negra. Metropolitan Museum Journal 33: 109-136.

ScotT, D.A., 2000. A review of gilding techniques in ancient South America, in T. Drayman-Weisser (ed.), Gilded Metals: History, Technology and Conservation. London, Archetype Publications in association with The American Institute for Conservation of Historic and Artistic Works, 203-222.
ShimadA, I. and Griffin, J.A., 1994. Precious metal objects of the Middle Sicán. Scientific American 270(4): 60-67.

Vetter Parodi, L., 2006. Gold of ancient Peru. Lima, Roberto Gheller Doig Ed. 
